\title{
Přínosy kožní pěny Enstilar při léčbě psoriázy u starších osob
}

MUDr. Zuzana Dančová

Kožní oddělení, Oblastní nemocnice Kolín, a. s.

Geriatričtí pacienti trpící psoriázou bývají s terapií často nespokojeni a vyzkoušeli již různé způsoby terapie. Tato případová studie popisuje 72letého pacienta trpícího psoriázou od rané dospělosti. Postupně si prošel lokální léčbou, fototerapií i léčbou systémovou. Terapie kožní pěnou s fixní kombinací betamethasonu a kalcipotriolu (Enstilar) výrazně zlepšila stav pacienta. Navíc se ukázala kličová role lékové formy, nebot’ stejná fixní kombinace účinných látek v jiné formě (gel) nemusí být podle poznatků z této kazuistiky stejně účinná jako kožní pěna.

Klíčová slova: psoriáza, psoriasis geographica, pruritus, fototerapie, betamethason/kalcipotriol, methotrexát, léková forma, retinoidy.

\section{Osobní anamnéza}

Pacient ve věku 72 let trpí od 18 let psoriázou. Počáteční projevy na předloktích a bércích se postupně rozšiřovaly až do stavu psoriasis geographica. Postižení nehtů a psoriatickou artritidu pacient neguje. V průběhu života nikdy nedošlo ke kompletní remisi onemocnění. Kožní nález se pacientovi zhoršuje při psychickém napětí a v podzimních

Obr. 1. Pred zahájením léčby

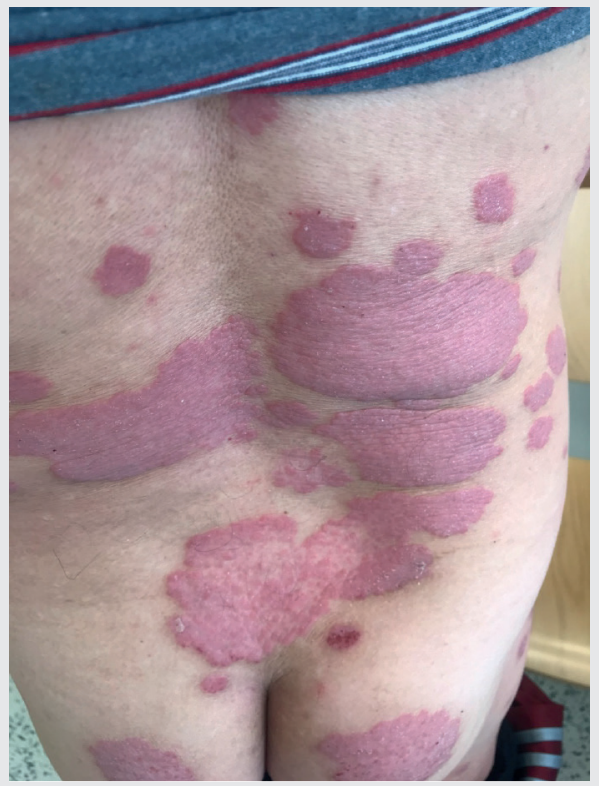

měsících. Psoriáza se v rodinné anamnéze objevuje jen u pacientova bratrance z otcovy strany.

Polymorbidní pacient se kromě psoriázy léčí s acinárním prostatickým karcinomem (aktuálně s neadjuvantní hormonální terapií). Je sledován také kvůli cervikokraniálnímu syndromu a spondyloartróze. Dřive se léčil s rotačním vertigem a jednostrannou nedo-

Obr. 2. Po 1 měsíci

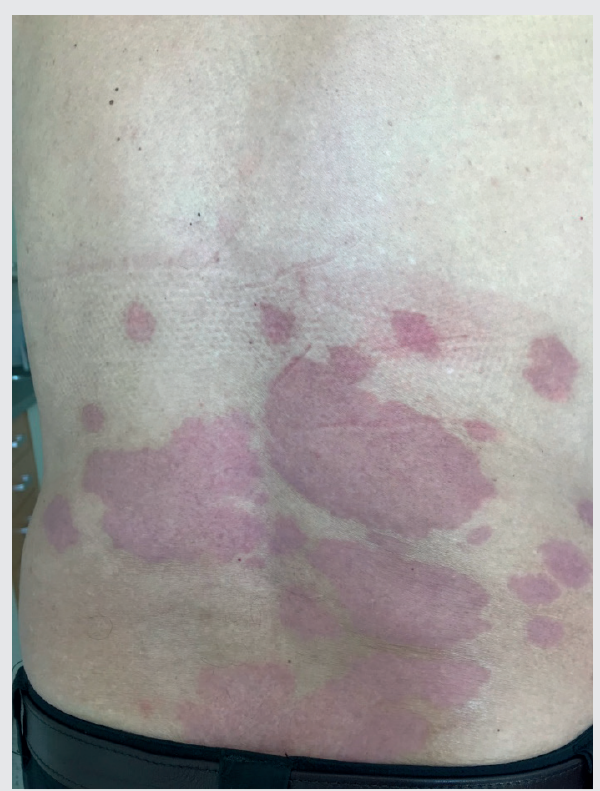

slýchavostí. Absolvoval několik ortopedických a břišních operací. Dlouhodobě užívá Trombex a Orcal. Pacient udává alergii na Mydocalm.

\section{Objektivní nález} a předchozí léčba

Při vstupním vyšetření před zahájením léčby pěnou Enstilar bylo stanoveno postižení tělesného povrchu (BSA) na více než 30 \%. Skóre

Obr.3. Po 3 měsících

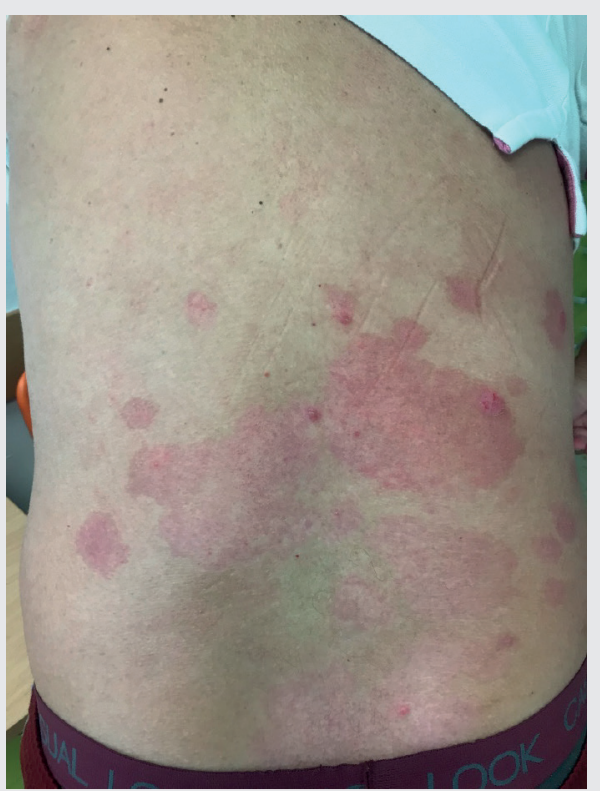




\section{KOMERČNÍ PREZENTACE}

\section{Obr.4. Před zahájením léčby}

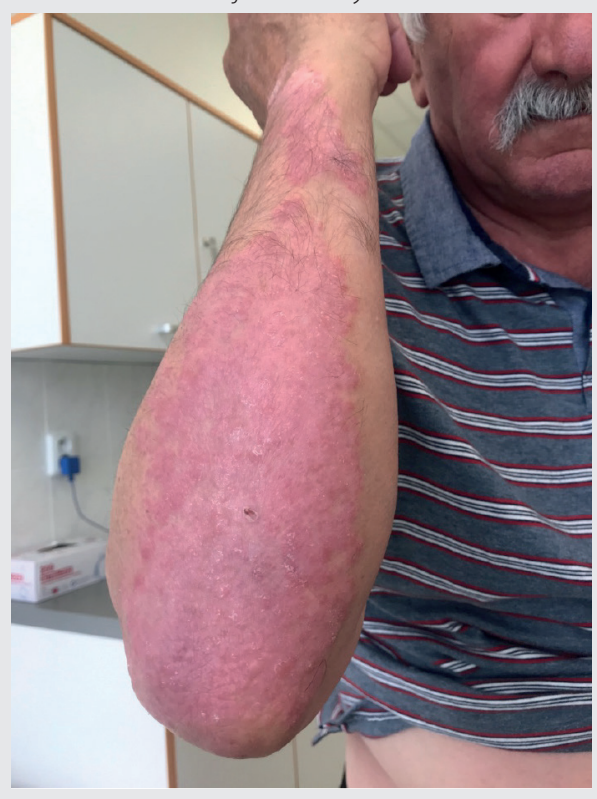

PASI určené pro hodnocení závažnosti a rozsahu psoriázy bylo 16,2. Pacient udává mírný pruritus.

Léčba $v$ minulosti probíhala $v$ různých kožních ambulancích a pacient vyzkoušel různé způsoby terapie. Lokální intervalová terapie kortikosteroidy (betamethason, dexamethason), emoliencia, topická léčba kalcipotriolem a fototerapie přinášely vždy jen přechodné zlepšení.

V polovině roku 2011 začal pacient kvưli nelepšícímu se kožnímu nálezu užívat systémové retinoidy. Stav se zlepšil, psoriatická ložiska byla hladká, bez infiltrace a šupin. Po 7 měsících léčby došlo kvůli výskytu nežádoucích účinků (olupování dlaní a plosek) ke snižení dávky. Po dalším roce byla terapie retinoidy ukončena kvưli vertigu a bolesti hlavy.

Léčba dále pokračovala topickou aplikací kortikosteroidů a fototerapií, muž používal také kyselinu salicylovou a gel s kombinací látek
Obr. 5. Po 1 mésíci

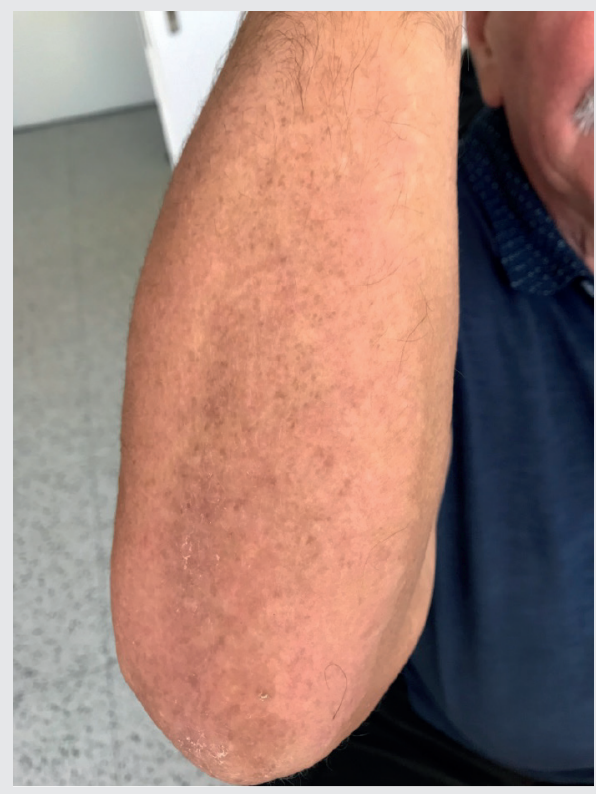

betamethason/kalcipotriol. Zlepšení stavu trvalo do roku 2017, kdy ošetřující lékař kvưli výraznému zhoršení kožního nálezu přistoupil k systémové léčbě methotrexátem. Po roce a půl této terapie byla léčba s neuspokojivým výsledkem ukončena.

\section{Doporučená terapie a výsledky léčby}

V květnu 2019 byla u pacienta zahájena topická léčba kožní pěnou s fixní kombinací betamethasonu a kalcipotriolu (Enstilar). Pacient nadále užival emoliencia. Po měsíci léčby kožní pěnou se jeho stav výrazně zlepšil a míra postižení hodnocená ukazatelem PGA byla na stupni 1. Pacient udával výbornou snášenlivost prípravku, vyzdvihoval zejména velmi dobrou roztíratelnost a přetrvávající pocit promaštěné pokožky. Žádné nežádoucí účinky léčby se u pacienta nevyskytly.
Obr.6. Po 3 mésících

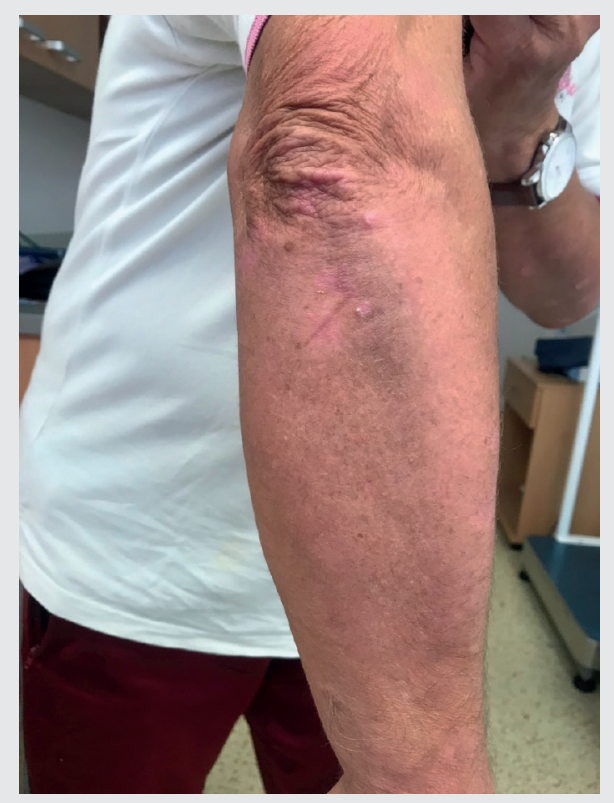

Po třech měsících terapie kožní pěnou byl stav nadále hodnocen jako velmi dobrý, pacient popisoval efekt léčby jako nejlepší ze všech absolvovaných terapií. Postižení tělesného povrchu (BSA) kleslo pod $10 \%$. Na některá ložiska na dolních končetinách si pacient aplikuje pěnu denně, u reziduálních ložisek stačí aplikace $2 \times$ týdně.

\section{Závěr}

Kazuistika dokládá prínosy fixní kombinace betamethasonu a kalcipotriolu ve formě kožní pěny u pacientů s rozsáhlými ložisky psoriázy. Výsledky léčby ukazují, že vhodně zvolená topická léčba může přinést výrazný efekt a zhojení ložisek i u pacientů, kteři v minulosti absolvovali neúspěšnou systémovou léčbu. Významnou roli hraje též léková forma, nebot’ stejná fixní kombinace účinných látek vjiné formě (gel) nemusí být podle poznatků z této kazuistiky stejně účinná jako kožní pěna. 